\title{
Physiological, Chemical and Ultrastructural Characteristics of Corynebacterium rubrum
}

\author{
By J. A. SERRANO, REYNA V. TABLANTE, \\ ANNA A. DE SERRANO, GIOCONDA C. DE SAN BLAS AND T. IMAEDA \\ Centro de Microscopia Electrónica, Universidad de Los Andes, Mérida, Venezuela and \\ Centro de Microbiología, Instituto Venezolano de Investigaciones Cientificas, \\ Apartado 1827, Caracas, Venezuela
}

(Accepted for publication 17 November 1971)

SUMMARY

A study of the ultrastructural characteristics, the physiological properties and an analysis of hydrolysates of phenol-treated cell walls of Corynebacterium rubrum were made. While the arabinogalactan-peptidoglycan complex found in the cellwall hydrolysates was that common to the genera Corynebacterium, Mycobacterium and Nocardia, the ultrastructural patterns found, the physiological reactions observed, the sensitivity to nocardiophages but not to corynebacteriophages or mycobacterial phages, and the (previously reported) presence of nocardomycolic acids, combined with the absence of corynemycolic acids and mycolic acids, indicate that this species belongs in the genus Nocardia rather than in the genus Corynebacterium.

It is proposed, therefore, that Corynebacterium rubrum be renamed Nocardia corynebacteriodes nomen novum.

\section{INTRODUCTION}

Corynebacterium rubrum was described by Crowle (1962). Gordon (1966) proposed the reclassification of this species as a member of the 'rhodochrous' group. The ultrastructure of wild-types of the genera Mycobacterium, Nocardia and Corynebacterium has been investigated and revealed structural differences in their cell walls (Imaeda \& Ogura, 1963; Kawate \& Inoue, 1965; Farshtchi \& McClung, 1967; Lickfeld, 1967; Montez \& Black, I967; Imaeda, Kanetsuna \& Galindo, I968; Beaman \& Shankel, I969; Hard, 1969).

The phenol-treated cell wall is composed of a mycolic acid-arabinogalactan-peptidoglycan complex, the common structural component of mycobacterial cell walls (Kanetsuna, I968), suggesting that this complex may be of taxonomic significance.

The purpose of this study was to examine the physiological and ultrastructural characteristics of Corynebacterium rubrum in relation to its classification. Chemical and morphological analyses were made of cell wall components obtained by various chemical and enzymatic treatments.

\section{METHODS}

Corynebacterium rubrum ATCCI 4898 was maintained on tryptose-phosphate broth (TPB) Difco, supplemented with $5 \%$ glycerol and $0.04 \%$ Tween 80 , for ultrastructural and chemical studies.

For physiological studies, nutrient broth, brain heart infusion (BHI) broth, glucose yeast extract medium (Waksman, 1950), Kirchener's medium (Crowle, 1962), Farshtchi's medium (Farshtchi \& McClung, I967), Middlebrook $7 \mathrm{H}_{9}$ glucose and Lowenstein-Jensen medium 
(Difco) were used. Sugar tests were carried out according to the methods recommended by Barksdale, Li, Cummins \& Harris (1957), Gordon \& Mihm (1957, 1959); Edwards \& Ewing, (I962) and Gordon (I966). Carbohydrates ( $1 \%$ w/v) were sterilized by filtration and added aseptically to the medium. Glucose was used at $1 \cdot 5 \%$ final concentration.

Organic acids as carbon source used at $0.2 \%$ final concentration (Gordon \& Mihm, 1957). Tests for indole production, methyl-red, Voges-Proskauer, $\mathrm{H}_{2} \mathrm{~S}$ production, growth in $\mathrm{KCN}$, nitrate reduction and decarboxylation of amino acids were made by the methods recommended by Edwards \& Ewing (1962).

Cultural condition for ultrastructural and chemical studies. Cultures in liquid media were aerated on an orbital shaker at $37^{\circ}$ for morphological studies. For cell-wall preparations, organisms grown in liquid media for I week at $37^{\circ}$ without shaking were killed with formaldehyde ( $0.5 \%$ final concentration). After several hours the bacteria were sedimented at $3000 \mathrm{~g}$ in a Sorvall KSB system and washed in distilled water. All procedures were performed at 23 to $25^{\circ}$.

Treatment of cell wall. The washed bacteria were freeze-dried in a 'Virtis' lyophilizer. The dried cells were extracted with neutral solvents at 23 to $25^{\circ}$ : ethanol-ether I: I (v/v) for I week, chloroform for $24 \mathrm{~h}$, acetone for $24 \mathrm{~h}$, successively. Organisms without free lipids were washed with distilled water several times and centrifuged at $10000 \mathrm{~g}$ for $15 \mathrm{~min}$. They were disrupted in a mortar with dry ice, followed by sonication at $20 \mathrm{kHz}$ for $\mathrm{I} \mathrm{h}$ with a Branson sonifier in an ice bath.

The suspension was centrifuged at $1500 \mathrm{~g}$ for $20 \mathrm{~min}$ to discard unbroken cells and the supernatant fluid was recentrifuged at $10000 \mathrm{~g}$ for $30 \mathrm{~min}$.

Sediments were treated with $0.5 \%$ trypsin (Sigma) in 0.1 M-phosphate buffer pH 7.6 at $37^{\circ}$ for $6 \mathrm{~h}$ to remove the remaining cytoplasmic components. Insoluble material was collected by centrifuging at $10000 \mathrm{~g}$ for $20 \mathrm{~min}$ and washed in distilled water several times. The cell walls thus prepared were examined with a Baush \& Lomb Spectronic 600 spectrophotometer at wavelengths ranging from 230 to $300 \mathrm{~nm}$ to check for the presence of nucleic acids as an indication of cytoplasmic contaminants. The preparation not showing any specific absorbance at $260 \mathrm{~nm}$ was used as the cell-wall fraction.

Treatment of the cell walls with $90 \%$ (w/v) phenol was performed (Imaeda et al. I968; Kanetsuna, I968) to obtain the lipopolysaccharide peptidoglycan complex; $45 \%(\mathrm{w} / \mathrm{v})$ phenol was also used to eliminate free protein and lipopolysaccharide from the phenolinsoluble lipopolysaccharide-peptidoglycan complex. Cell walls were also treated with $0.1 \%$ pancreatin in $0.1 \mathrm{M}$-phosphate buffer at $\mathrm{pH} 7.6$ for $6 \mathrm{~h}, 5 \%$ TCA at 4 for $72 \mathrm{~h}$ or $0.4 \%$ sodium dodecyl sulphate (SDS) (Sigma).

Chemical analysis of phenol-treated cell-wall fractions. For the determination of sugars, lipids, amino sugars and amino acids, samples of cell walls were examined as previously described (Kanetsuna, I968). Quantitative determination of amino acids was carried out with a JEOL amino acid analyser JLC-3 BC.

Electron microscopy. Whole organisms and cell walls, either without treatment or after treatment with different neutral solvents, were positively or negatively stained with $2 \%$ sodium silicotungstate at $\mathrm{pH} 7 \cdot 5$.

To obtain ultrathin sections the organisms at various stages of growth were centrifuged, and fixed by the methods of Ryter \& Kellenberger (1958). Fixation with $4 \%$ formaldehyde in $0.15 \mathrm{M}$-tris- $\mathrm{HCl}$ buffer $\mathrm{pH} 7.4$ containing I $\% \mathrm{NaCl}$ and $0.2 \% \mathrm{CaCl}_{2}$ by a modification of Stoeckenius method (Stoeckenius \& Rowen, I967; Imaeda et al. 1969) was also employed, followed by treatment with I \% osmium tetroxide or I \% potassium permanganate. After dehydration with acetone, cells were embedded in Araldite. 


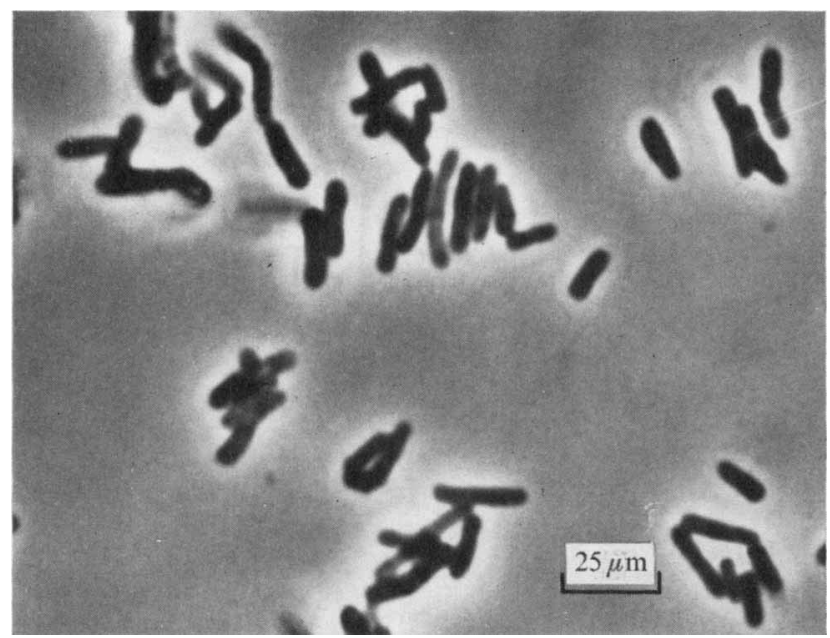

Fig. I. Phase-contrast micrograph of cells of Corynebacterium rubrum. Note the cells in pairs, $\checkmark$ forms, clumps and palisade arrangements.

\section{Table I. Physiological characteristics of Corynebacterium rubrum}

Test

Indole

Methyl-red

Voges-Proskauer

Growth at $10^{\circ}$

Growth at $40^{\circ}$

Growth at $45^{\circ}$

Survival of $60^{\circ}, 4 \mathrm{~h}$

Sensitive to $0.01 \%$ methyl violet

Sensitive to $0.01 \%$ pyronin B

Sensitive to $0.01 \%$ brilliant green

Decomposition of casein

Decomposition of gelatin

Decomposition of tyrosine

Decomposition of xanthine

Hydrolysis of starch

Hydrolysis of hippurate

Catalase

Urease

Nitrate reduction

Motility

Acid from adonitol

Acid from arabinose

Acid from cellobiose

Acid from dulcitol

Acid from fructose

Acid from galactose

Acid from glucose

Acid from inositol

Acid from inulin
Results
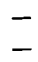

-

$+$

$+$

-

* This activity is inhibited by warming the cells at $68^{\circ}$ in water bath for $20 \mathrm{~min}$.
Results

Acid from lactose

Acid from mannitol

Acid from mannose

Acid from melibiose

Acid from raffinose

Acid from rhamnose

Acid from sorbitol

Acid from sorbose

Acid from sucrose

Acid from trehalose

Acid from xylose

Utilization of acetate

Utilization of citrate

Utilization of malate

Utilization of lactate

Utilization of pyruvate

Utilization of succinate

Growth in $\mathrm{KCN}$ medium

Phenylalanine deaminase

Alanine

Arginine

Cysteine

Hydrogen sulphide production

Oxidation-fermentation test

medium (Hugh \& Leifson, I953)

Haemolysis 


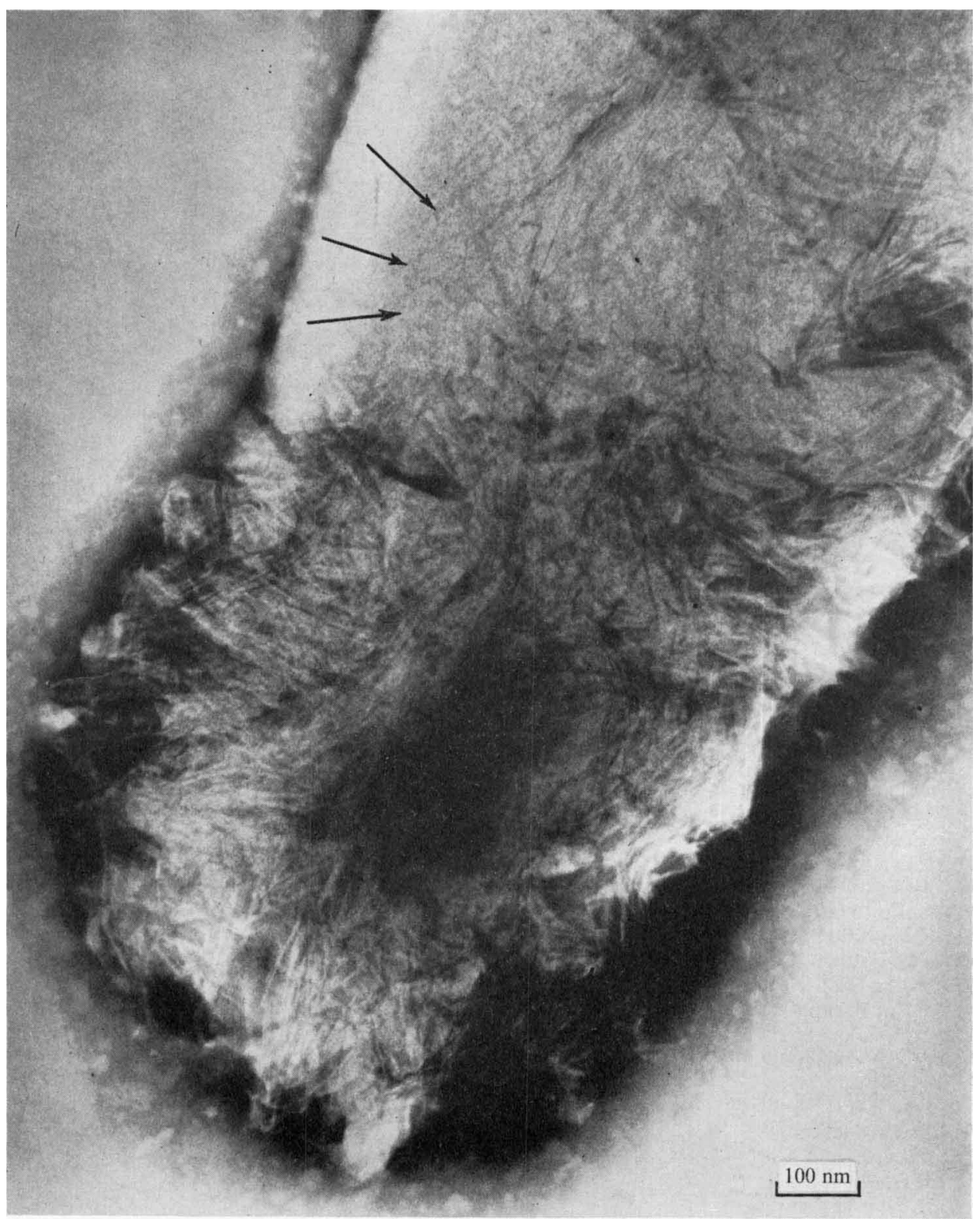

Fig. 2. Electron micrograph showing negatively stained (silicotungstate) Corynebacterum rubrum after 20 min agitation in physiological saline. Note how the 'fibrillar-like' substance that covers the surface of the cell has been partially removed (arrows) by this treatment.

The ultrathin sections were cut with a MT-2 Porter-Blum ultramicrotome and double stained with uranyl acetate and lead citrate. The electron microscopes used were a Hitachi HU-I I B, HS-6 and JEM 7-A. 


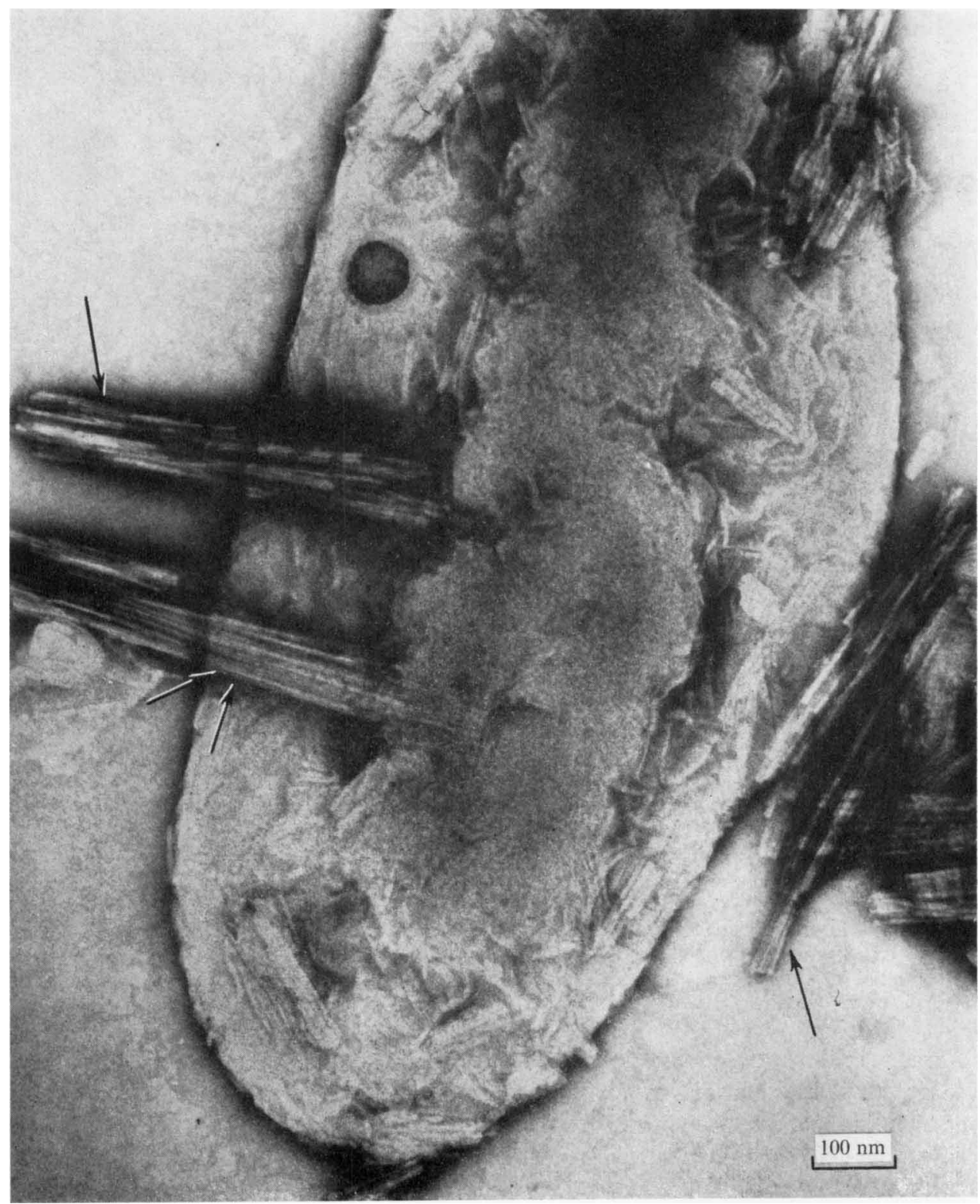

Fig. 3. Electron micrograph of a negatively stained (silicotungstate) Corynebacterium rubrum cell. Treated with acetone. The fibrillar-like substance shown in Fig. 2 appears now as a crystal-like structure (arrows).

\section{RESULTS}

Physiology and gross morphology of Corynebacterium rubrum

Corynebacterium rubrum is aerobic. It grows in tryptose phosphate, nutrient broth, brain-heart infusion broth (Difco), glucose-yeast extract medium and Lowenstein-Jensen media, at $37^{\circ}$, in chemically defined media such as Kirchener's medium and Middlebrook ${ }_{7} \mathrm{H}_{9}$ glucose (Difco). In stationary liquid media growth starts with the production of a fine 

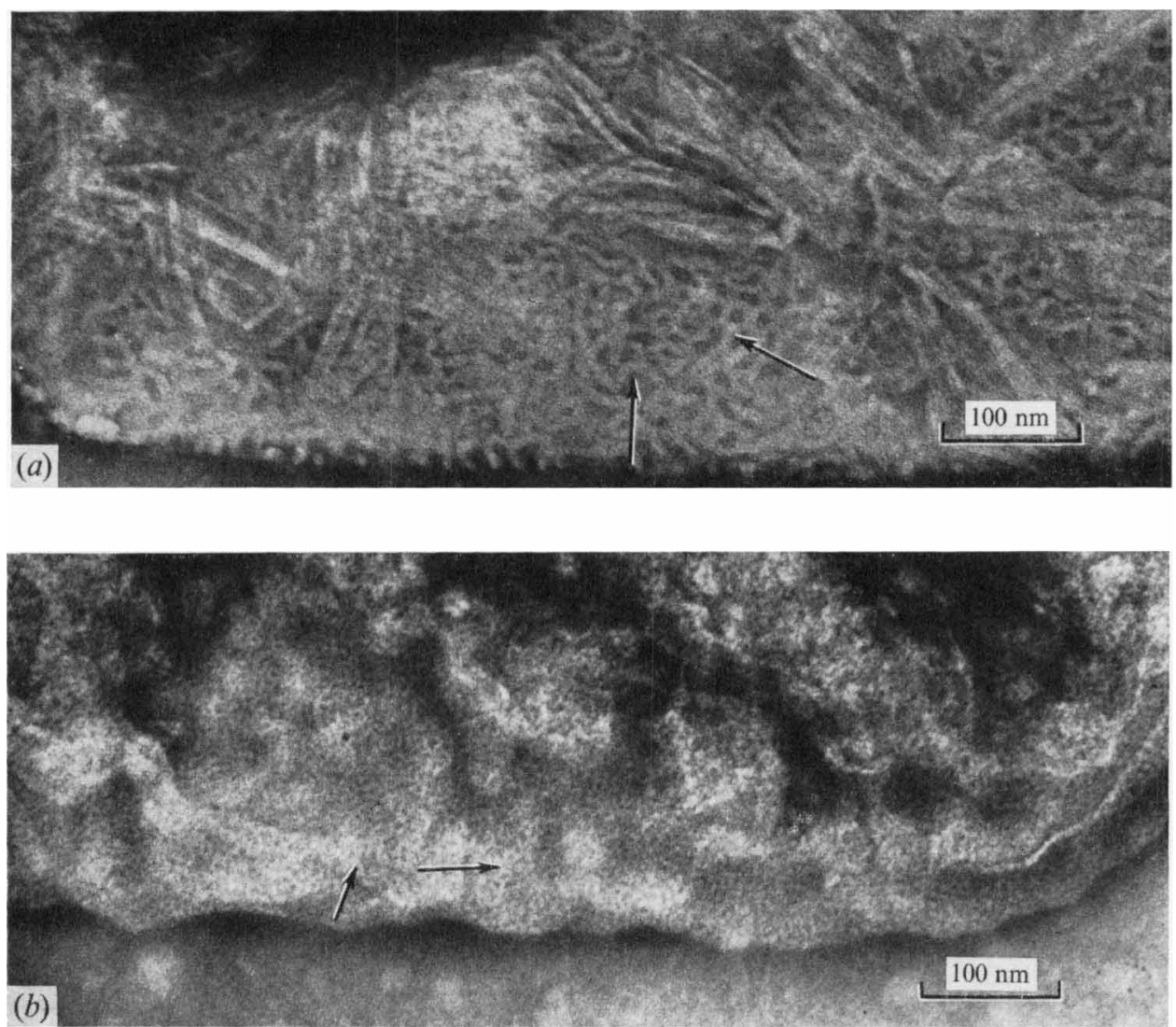

Fig. 4. (a) Electron micrographs of negatively stained (silicotungstate) Corynebacterium rubrum cells. (a) Treatment with $0 . \mathrm{I} \%$ pancreatin $\left(6 \mathrm{~h}\right.$ at $\left.37^{\circ}\right)$ partially removed the fibrillar-like substance from the surface, disclosing an underlying network of fibrils 8 to Io $\mathrm{nm}$ in diam. (arrows). (b) After phenol extraction, both the outermost fibrillar-like substance and the underlying network of fibrils observed in ( $a$ ) were removed. An innermost network of fibrils (arrows) with a mean diam. of about $4 \mathrm{~nm}$ is now detected.

dark-orange sediment which after about $35 \mathrm{~h}$ at $37^{\circ}$ forms an orange-red film on the surface of the media. Colour becomes more intense in the glucose yeast extract media. In chemically defined media the orange-red film appears more rapidly and has a dry appearance. On solid media orange-red pigmented colonies with a granular central region are surrounded by a smooth and shiny peripheral zone.

By phase-contrast bacterial cells were seen in pairs, $V$ forms, clumps and palisade arrangements (Fig. I). It is Gram-positive, not acid-fast, and has metachromatic granules and lipophilic granules in its cytoplasm when stained by Albert's method or with oil red $O$. Results of the physiological tests applied to the Corynebacterium rubrum are presented in Table I.

Corynebacterium rubrum is sensitive to Io i.u. bacitracin $/ \mathrm{ml}$, and 2 i.u. penicillin $/ \mathrm{ml}$ in quantitative antibiotic sensitivity test and sensitive to $2 \mathrm{mg}$ lincomycin, $10 \mu \mathrm{g}$ oxytetracycline, Io $\mu \mathrm{g}$ chloramphenicol, $5 \mathrm{mg}$ neomycin, $2 \mathrm{mg}$ erythromycin, I $\mu \mathrm{g}$ sulphathiazole, $25 \mu \mathrm{g}$ ampicillin, $2 \mu \mathrm{g}$ dehydrostreptomycin, $30 \mu \mathrm{g}$ novobiocin and $25 \mu \mathrm{g}$ cephalotin in qualitative sensitivity test with antibiotic discs (Difco). 


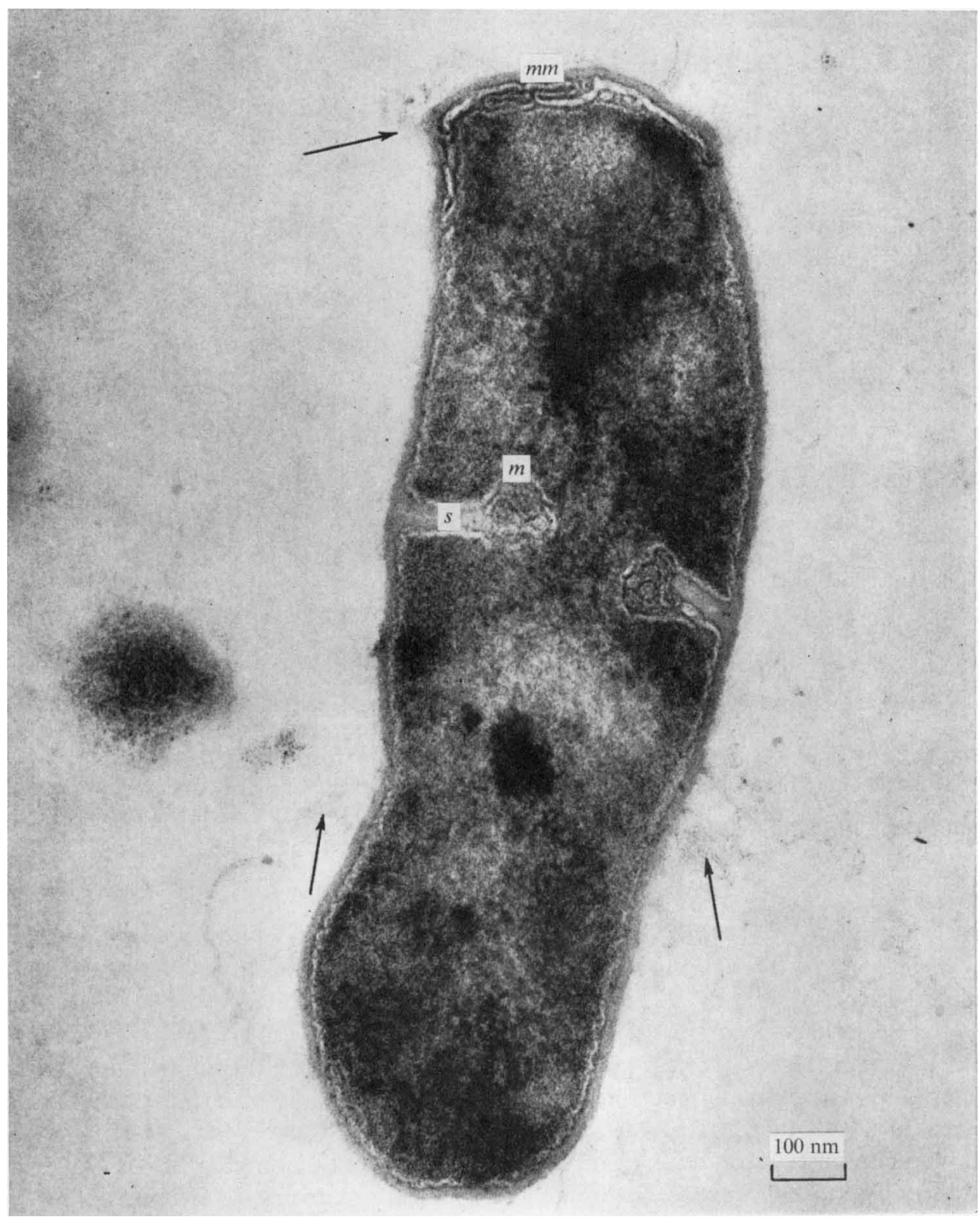

Fig. 5. Electron micrograph of a longitudinal section of a Corynebacterium rubrum cell after double fixation with formaldehyde and $\mathrm{OsO}_{4}$. The fibril-like structure (arrows) is observed adherent to the outermost surface of the cell. Note the vesicular structure of the mesosome $(m)$ in relation to the septum $(s)$. Remains of mesosome membranes are also detected $(\mathrm{mm})$.

\section{Ultrastructure}

Negatively stained cells of Corynebacterium rubrum are covered with a fibril-like substance (Fig. 2) which can be partially removed by sonication and neutral solvents. Treatment with neutral solvents transforms fibrils into a crystal-like substance in situ or after they are 


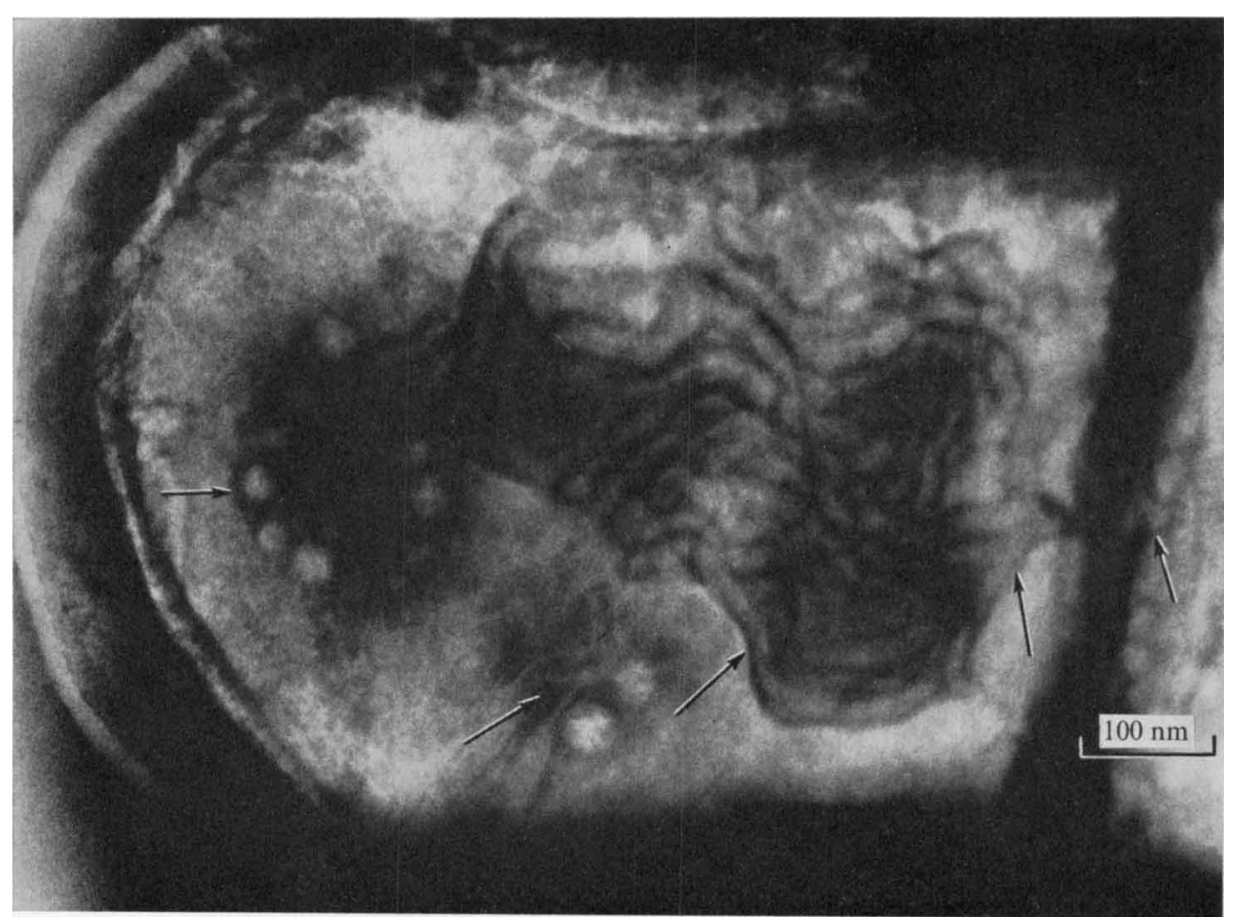

Fig. 6. A positively stained (silicotungstate) Corynebacterium rubrum cell, during active division. The formation of the septum is completed and the mesosomes with a tubular appearance are seen at both sides of the septum. Structures similar to those described as polyphosphate granules are also detected within the cells.

removed from the cell surface (Fig. 3). The shape of the crystal-like material is not altered by treatment with $0.5 \%$ trypsin, pancreatin or pepsin. This outermost fibrillar layer, which may correspond to the outermost diffuse dense layer seen in ultrathin sections (Fig. 5) is a unique surface substance of this species and has never been observed by us on the surface of any mycobacterium, nocardia or corynebacterium.

When the organisms were agitated for 20 min with physiological saline, the outermost fibrillar layer was partially removed disclosing an underlying layer. Treatment with $0 \cdot 1 \%$ pancreatin at $37^{\circ}$, or $5 \%$ TCA at $4^{\circ}$ also removed the outermost layer. The underlying layer was composed of a network of fibrils of 8 to ro $\mathrm{nm}$ diam. (Fig. 4 a). SDS $(0.4 \%$ ) and phenol removed completely the innermost fibrillar network layer containing fibrils of about $4 \mathrm{~nm}$ diam. (Fig. $4 b$ ).

In ultrathin sections the cell wall is composed of an outermost diffuse layer and a middle moderately dense layer $10 \mathrm{~nm}$ thick which adheres to the plasma membrane. The total thickness of the cell wall is about $\mathrm{I} 8$ to $20 \mathrm{~nm}$. The plasma membrane is often seen to be continuous with the mesosome.

In the cytoplasm, granules possibly representing polyphosphate are observed along with other cytoplasmic structures such as ribosomes and a nuclear region (Fig. 5, 6). The mesosome in positively stained cells is revealed as a tubular structure which appears to be lamellar or vesicular in ultrathin sections (Fig. 6); occasionally the mesosome shows contact with the nuclear area. 
Table 2. Chemical composition of the phenol-treated cell walls of Corynebacterium rubrum

Values are expressed in $\%(w / w)$

$\begin{array}{ccccc}\text { Strain } & \begin{array}{c}\text { Pentose as } \\ \text { arabinose }\end{array} & \begin{array}{c}\text { Hexose as } \\ \text { galactose }\end{array} & \begin{array}{c}\text { Amino sugar } \\ \text { as glucosamine }\end{array} & \begin{array}{c}\text { Amino acid } \\ \text { as alanine }\end{array} \\ \text { C. rubrum } & 13.7 & 24.9 & 6.2 & 22.6\end{array}$

Table 2 shows the chemical composition of the phenol-treated cell walls of Corynebacterium rubrum. This fraction has $\alpha, \epsilon$-diaminopimelic acid, glutamic acid and alanine as the principal amino acids and glucosamine and muramic acid as the principal amino sugars.

The molar ratio of diaminopimelic acid, glutamic acid, alanine, muramic acid and glucosamine is I:I:I.9:0.9:0.9. The sugars contained in this fraction are arabinose and galactose. These components may be considered to form an arabinogalactan-peptidoglycan complex, as reported in Mycobacterium and Nocardia (Cummins \& Harris, I958; Kanetsuna, I968; Cunto, Kanetsuna \& Imaeda, 1969). There are not mycolic acids in this fraction.

\section{DISCUSSION}

On physiological characteristics, Corynebacterium rubrum has been included within the 'rhodochrous' group. The physiological assays that were carried out during this investigation lead us also to consider that this species does not belong to the genus Corynebacterium but rather to be more closely related to Mycobacterium or Nocardia. However, the ultrastructure of C. rubrum is different from that observed in wild-type of strains of Corynebacterium.

For example, the presence of an outermost dense cell-wall layer in Corynebacterium minutissimum, Corynebacterium diphtheriae and Corynebacterium ovis (Lickfeld, 1967; Montez \& Black, 1967; Hard, 1969) and the multiseptum formation sometimes observed in $C$. diphtheriae (Lickfeld, I967) make these species very different from Corynebacterium rubrum. On the other hand, several mutants of mycobacteria which contain red pigment show very similar ultrastructural characteristics to those of C. rubrum (T. Imaeda, personal communication).

Many human and animal pathogenic corynebacteria and many mycobacteria and nocardia cell walls are characterized by arabinose, galactose and $\alpha, \epsilon$-diaminopimelic acid (Cummins \& Harris, 1958). The presence of this polymer in the Corynebacterium rubrum cell wall is not conclusive evidence that this species belongs to the genera Corynebacterium, Mycobacterium or Nocardia, but the isolation of nocardomycolic components from cellwall analyses of C. rubrum (M. A. Lanelle, B. L. Beaman and W. L. Barksdale, personal communication) showed it to have low-molecular-weight nocardomycolic acids, suggesting that its taxonomic position was closer to Nocardia rubra than to Nocardia asteroides or Nocardia brasiliensis. Lechevalier, Horan \& Lechevalier (1971) also reported the presence of nocardomycolic acid in C. rubrum and suggested that C. rubrum was lysed only by nocardiophages, but not by mycobacterial phages or by corynebacteriophages (Arden, 1970).

Based on the comparisons of ultrastructure, physiological characteristics, cell-wall composition and phage sensitivity it is concluded that Corynebacterium rubrum should be included in the genus Nocardia. It is proposed that this species be named Nocardia 
corynebacteroides. The change in specific epithet is needed because the combination Nocardia rubra is pre-empted by Nocardia rubra (Kruse) Chalmers \& Christopherson, which combination, according to Buchanan, Holt \& Lessel (I966), is validly published and legitimate.

This research was partially supported by Consejo de Desarrollo Científico y Humanístico de la Universidad de Los Andes, Mérida, Venezuela, and was done in partial fulfilment of the requirements for the doctoral degree in the University of Sâo Paulo, Brazil, by J. A. Serrano.

We wish to thank Miss Cecilia Maldonado and Mr Ramón Sulbarán for their valuable help in the elaboration of this work, and to Dr L. Barksdale and S. B. Arden for their suggestions, criticism and comments on the manuscript.

\section{REFERENCES}

ARden, S. B. (1970). Comparative studies of Corynebacterium diphtheriae, C. ovis, C. ulcerans and related species. Ph.D. Thesis, New York University.

Barksdale, W. L., Li, K., Cummins, C. S. \& Harris, H. (1957). The mutation of Corynebacterium pyogenes to Corynebacterium haemolyticum. Journal of General Microbiology 16, 749-758.

Beaman, B. L. \& Shankel, D. M. (1969). Ultrastructure of nocardia cell growth and development on defined and complex agar media. Journal of Bacteriology 99, 876-884.

Buchanan, R. E., Holt, J. G. \& Lessel, E. F. Jun. (r966). Index Bergeyana. Baltimore: Williams \& Wilkins.

Crowle, A. J. (1962). Corynebacterium rubrum nov.spec. A Gram-positive non acid-fast bacterium of unusually high lipid content. Antonie van Leeuwenhoek 28, 182-192.

Cummins, C. S. \& HarRis, H. (1958). Studies on the cell wall composition and taxonomy of Actinomycetales and related groups. Journal of General Microbiology 18, I73-189.

Cunto, G., Kanetsuna, F. \& Imaeda, T. (I969). Chemical analysis of the mucopeptide of Mycobacterium smegmatis. Biochimica et biophysica acta 192, 358-360.

EdwaRds, P. R. \& EWING, W. H. (1962). Identification of Enterobacteriaceae, 2nd edn. Minneapolis: Burgess Publishing Co.

FARSHTCHI, D. \& MCLUNG, M. N. (1967). Fine structure of Nocardia asteroides grown in chemically defined medium. Journal of Bacteriology 94, 255-257.

Gordon, R. E. (1966). Some strains in search of a genus-Corynebacterium, Mycobacterium, Nocardia or what? Journal of General Microbiology 43, 329-343.

GoRDon, R. E. \& MiHM, J. M. (1957). A comparative study of some strains received as nocardiae. Journal of Bacteriology 73, I5-27.

Gordon, R. E. \& Miнm, J. M. (1959). A comparison of four species of mycobacteria. Journal of General Microbiology 21, 736-748.

HARD, G. C. (1969). Electron microscopic examination of Corynebacterium ovis. Journal of Bacteriology $\mathbf{9 7}$, I $480-1485$.

Hugh, R. \& LeIrSON, E. (I953). The taxonomic significance of fermentative versus oxidative metabolism of carbohydrates by various Gram-negative bacteria. Journal of Bacteriology 66, 24-26.

ImAedA, T., Kanetsuna, F. \& Galindo, B. (I968). Ultrastructure of cell walls of genus Mycobacterium. Journal of Ultrastructure Research 25, 46-63.

ImAeda, T., Kanetsuna, F., Galindo, G., Rieber, M. \& Cesari, I. (I969). Ultrastructural characteristics of mycobacterial growth. Journal of Medical Microbiology 2, 18I-186.

ImAeDA, T. \& OGURA, M. (1963). Formation of intracytoplasmic membrane system of mycobacteria related to cell division. Journal of Bacteriology 85, I50-163.

KANETSUNA, F. (1968). Chemical analyses of mycobacterial cell walls. Biochimica et biophysica acta $\mathbf{1 5 8}$, 138-I43.

KAWATA, T. \& INOUE, T. (1965). Ultrastructure of Nocardia asteroides as revealed by electron microscopy. Japanese Journal of Microbiology 9, IOI-II4.

Lechevalier, M. P., Horan, A. C. \& Lechevalier, H. (I97I). Lipid composition in the classification of nocardiae and mycobacteria. Journal of Bacteriology 105, 313-318.

LiCKFELD, G. K. (1967). Die elecktronenmikroskopischen Untersuchungen. Zeitschrift fïr medizinische Mikrobiologie, Immunologie und Virologie 153, 326-339. 
MONTEZ, L. F. \& BLACK, S. H. (1967). The fine structure of Corynebacterium minutissimum. Experientia 23, $345-346$.

Ryter, A. \& Kellenberger, E. (1958). Étude au microscope electronique de plasma contenant de l'acide desoxyribonucleique. I. Les nucleosides des bactéries en croissance active. Zeitschrift für Naturforschung 136, 387-605.

Stoeckenius, W. \& Rowen, R. (I697). A morphological study of Halobacterium halobium and its lysis in media of low salt concentration. Journal of Cell Biology 34, 365-393.

WaKSMAN, S. A. (1950). The actinomycetes. Annals Crytogamici et phytopathologici 9, 196. 